\title{
Leaf morphophysiology of a Neotropical mistletoe is shaped by seasonal patterns of host leaf phenology
}

\author{
Marina Corrêa Scalon ${ }^{1} \cdot$ Davi Rodrigo Rossatto ${ }^{2}$. \\ Fabricius Maia Chaves Bicalho Domingos ${ }^{3}$ Augusto Cesar Franco ${ }^{1}$
}

Received: 21 April 2015 / Accepted: 24 November 2015 / Published online: 19 December 2015

(C) Springer-Verlag Berlin Heidelberg 2015

\begin{abstract}
Several mistletoe species are able to grow and reproduce on both deciduous and evergreen hosts, suggesting a degree of plasticity in their ability to cope with differences in intrinsic host functions. The aim of this study was to investigate the influence of host phenology on mistletoe water relations and leaf gas exchange. Mistletoe Passovia ovata parasitizing evergreen (Miconia albicans) hosts and P. ovata parasitizing deciduous (Byrsonima verbascifolia) hosts were sampled in a Neotropical savanna. Photosynthetic parameters, diurnal cycles of stomatal conductance, pre-dawn and midday leaf water potential, and stomatal anatomical traits were measured during the peak of the dry and wet seasons, respectively. $P$. ovata showed distinct water-use strategies that were dependent on host phenology. For $P$. ovata parasitizing the deciduous host, water use efficiency (WUE; ratio of photosynthetic rate to transpirational water loss) was 2-fold lower in the dry season than in the wet season; in contrast, WUE was maintained at the same level during the wet and dry seasons in $P$. ovata
\end{abstract}

Communicated by Hermann Heilmeier.

Electronic supplementary material The online version of this article (doi:10.1007/s00442-015-3519-8) contains supplementary material, which is available to authorized users.

Marina Corrêa Scalon

marina_scalon@yahoo.com.br

1 Laboratório de Ecofisiologia Vegetal, Departamento de Botânica, Instituto de Ciências Biológicas, Universidade de Brasília, Caixa Postal 04457, Brasília, DF 70904-970, Brazil

2 Laboratório de Ecologia Vegetal, Departamento de Biologia (FCAV), Universidade Estadual Paulista (UNESP), UNESP Campus de Jaboticabal, Jaboticabal, SP 14884-000, Brazil

3 Departamento de Zoologia, Instituto de Ciências Biológicas, Universidade de Brasília, Brasília, DF 70910-900, Brazil parasitizing the evergreen host. Generally, mistletoe and host diurnal cycles of stomatal conductance were linked, although there were clear differences in leaf water potential, with mistletoe showing anisohydric behaviour and the host showing isohydric behaviour. Compared to mistletoes attached to evergreen hosts, those parasitizing deciduous hosts had a 1.4-fold lower stomatal density and 1.2-fold wider stomata on both leaf surfaces, suggesting that the latter suffered less intense drought stress. This is the first study to show morphophysiological differences in the same mistletoe species parasitizing hosts of different phenological groups. Our results provide evidence that phenotypical plasticity (anatomical and physiological) might be essential to favour the use of a greater range of hosts.

Keywords Hemiparasite - Loranthaceae · Water use · Stomatal traits · Cerrado

\section{Introduction}

Mistletoes are hemiparasitic angiosperms that depend on their host to acquire all of the water and nutrients they need to survive (Calder and Bernhardt 1983; Press and Graves 1995). In terms of water use, mistletoes have been widely reported to exhibit higher transpiration rates and stomatal conductance than their host, but lower photosynthetic rates (Escher et al. 2004; Glatzel and Geils 2009; Ullmann et al. 1985). However, the maintenance of host integrity might be an essential condition for the successful survival and reproduction of the attached mistletoe (Stewart and Press 1990), suggesting that the outcome of the mistletoe-host interactions should strongly depend on host characteristics, with parallel responses to environmental conditions (Bowie and Ward 2004; Davidson and Pate 1992; Davidson et al. 
1989; Scalon and Wright 2015). For example, generalist mistletoes can grow on many different hosts, including species showing different leaf phenology (Okubamichael et al. 2011). The adequate availability of soil water for deep-rooted hosts might imply that the attached mistletoe would not need to rely on the regulation of water losses even during the peak of the dry season (Escher et al. 2008; Garkoti et al. 2002). In contrast, tight regulation of water loss would be essential for evergreen mistletoes parasitizing shallow-rooted evergreen hosts.

Parasitism in mistletoes evolved in a specific manner, with only a single opportunity for dispersal. Foraging and perching behaviour of the birds that disperse mistletoe seeds might define the range of potential hosts (Buen and Ornelas 1999; Ladley and Kelly 1996; Rawsthorne et al. 2011). Physiological compatibility of mistletoes with individual hosts is, however, crucial for the successful establishment, growth and reproduction of any mistletoe species (Shen et al. 2006). Once the seed is dropped by a bird onto the branch of a potential host, the chance of it being relocated to a more suitable host is nonexistent (Press and Phoenix 2005). Generalist mistletoes would therefore have the advantage over their specialist counterparts in terms of potentially greater dispersion rates and establishment success. However, with a greater range of potential hosts, mistletoes would also need to deal with the metabolic particularities of different hosts and might be subject to non-ideal physiological circumstances in terms of nutrient and water acquisition (Press and Phoenix 2005). To cope readily with these potential metabolic differences in a diverse assemblage of host species, generalist mistletoes are expected to show rapid metabolic adaptation rates and a high degree of phenotypic plasticity that should be reflected in their morphology and physiology. For example, different populations of the same species of mistletoe can display variations in morphology, such as differences in internode length, fruit size and fruit pigmentation (Glazner et al. 1988; May 1972). A high variation of leaf morphology and architecture within mistletoe species in relation to different host species and host populations has also been documented (Atsatt 1970; Herrera 1988; Medel et al. 1995). Physiological specialization has also been reported, such as the large amount of aluminium (Al) in leaves of mistletoes parasitizing Al-accumulator hosts in acidic soils (Lüttge et al. 1998; Scalon et al. 2013) and differences in freeze tolerance and flavonoid content between two populations of the same mistletoe species in distinct locations (May 1972).

The tropical mistletoe family Loranthaceae is represented by approximately 1000 species and is widely distributed over the southern hemisphere (Nickrent et al. 2010; Vidal-Russell and Nickrent 2007). In Brazil, the family Loranthaceae is represented by 12 genera and 131 species (Arruda et al. 2012), distributed over all of the major
Brazilian biomes. The Brazilian Loranthaceae Passovia ovata (Pohl ex DC.) Kuijt is reported to be a host generalist (Lüttge et al. 1998; Scalon et al. 2013) and has been found parasitizing both deciduous and evergreen trees, especially in the Brazilian Neotropical Savanna (Cerrado). The Cerrado is characterized by a strong seasonality, where most of the rainfall is restricted to the wet season (OctoberApril). During the dry season (May-September) plants are subjected to soil water deficits, and the canopy is exposed to high irradiance levels, elevated temperatures and high atmospheric vapour pressure deficits (Bucci et al. 2004; Franco et al. 2005). These conditions impose selective pressures on deciduous and evergreen plants for strong stomatal regulation of transpiration to maintain their water balance. However, the contrasting phenology of the two plant functional types (i.e. deciduous and evergreens) implies different strategies to regulate plant water balance (Franco et al. 2005) that would potentially affect any attached mistletoe, particularly in the dry season when the evaporative demand of the atmosphere is high and soil water resources are low. While evergreen trees retain a full canopy and exert strong stomatal control over transpiration to maintain plant water balance during a diurnal cycle, deciduous species remain leafless for varied periods of time in the dry season. Moreover, many deciduous species have very deep roots which can access moist soil layers and, therefore, the regulation of water loss would not be as critical as in evergreen species (Bucci et al. 2005; Jackson et al. 1999; Scholz et al. 2002).

The aim of this study was to investigate the effect of host phenology on water use strategies of the generalist mistletoe Passovia ovata in the Cerrado. We hypothesized that mistletoes parasitizing an evergreen host would adopt a stronger stomatal control over transpiration and that this control would enable them to maintain year-round homeostasis in leaf water potential in close association with changes in water balance and water loss of the host and, thereby, avoid increased water deficits during the dry season. In contrast, leaf loss would not only decrease the water demand of the deciduous host during the dry season, but it would also relieve competition for water between the host and the attached evergreen mistletoe, thereby reducing the need for strong stomatal regulation of transpiration. We also expected that these differences would be reflected in stomatal characteristics, in particular on stomatal density and guard cell dimensions of the attached mistletoe.

\section{Materials and methods}

The study was conducted in a Cerrado site located $35 \mathrm{~km}$ south of Brasília in the Federal District of Brazil $\left(15^{\circ} 56^{\prime} 41^{\prime \prime} \mathrm{S}, 47^{\circ} 53^{\prime} 07^{\prime \prime} \mathrm{W}\right)$, within the Nature Reserve of Roncador municipality, which belongs to the Brazilian 
Institute of Geography and Statistics (RECOR/IBGE). The study site is classified as a typical savanna (Cerrado sensu stricto), with a deep, well-drained, strongly acid dystrophic latosol ( $\mathrm{pH}$ of approx. 4.2) with high aluminium $\left(\mathrm{Al}^{3+}\right)$ saturation. The climate of the region is tropical, classified as Aw according to the Köppen Climate Classification System, with marked seasonality and an annual total rainfall of $1450 \mathrm{~mm}$, which occurs mostly during the wet season (from October to April). Evapotranspiration in the study area ranges from $1.9 \mathrm{~mm} \mathrm{day}^{-1}$ during the dry season to $3.5 \mathrm{~mm} \mathrm{day}^{-1}$ in the wet season (Maitelli and Miranda 1991; Miranda et al. 1997).

All measurements took place during the peaks of the wet (Jan 2009) and dry (Aug 2009) seasons, respectively. We sampled ten mistletoe $P$. ovata (Pohl ex DC.) Kuijt (Loranthaceae) plants, of which five were parasitizing Miconia albicans (Sw.) Steud. (Melastomataceae), an evergreen species, and five were parasitizing Byrsonima verbascifolia (L.) DC. (Malphighiaceae), a deciduous species. We measured the leaves of healthy, non-infected branches of the host plants. For both host plants and mistletoes, mature fully-expanded sun-exposed leaves without signs of senescence and herbivory were used for the analysis.

We used an LCi portable photosynthesis system (ADC BioScientific Ltd., Hoddesdon, Hertfordshire, UK) to measure maximum photosynthetic rates $\left(A_{\max }\right)$, stomatal conductance $\left(g_{\text {s-max }}\right)$ and leaf transpiration $(E)$ simultaneously. Briefly, the leaf cuvette was fitted with a halogen dichroic lamp that delivered a photosynthetic photon flux density of $1260 \mu \mathrm{mol} \mathrm{m}^{-2} \mathrm{~s}^{-1}$ at the leaf surface, which was sufficient irradiance to saturate photosynthesis in these plants (Franco et al. 2005). All measurements were performed during the period from 0800 hours to 1130 hours in three leaves of each individual, in a randomized design where we considered each mistletoe-host pair to be the experimental sampling unit. The temperature of the cuvette temperature ranged from $29.2{ }^{\circ} \mathrm{C}$ to $31.7{ }^{\circ} \mathrm{C}$ during the wet season and from $26.5{ }^{\circ} \mathrm{C}$ to $29.4{ }^{\circ} \mathrm{C}$ during the dry season and did not differ between mistletoes and host species-airs (paired $t$ test $P=0.159$ ). Leaf-to-air vapour pressure deficit (VPD) also did not differ between species pairs, but for all VPD measurements, the values varied from 0.9 to $2.3 \mathrm{kPa}$ during the wet season, and from 1.7 to $2.9 \mathrm{kPa}$ during the dry season. Water use efficiency (WUE) was calculated as the ratio of $A_{\max }$ and E. An AP4 porometer (Delta-T-Devices Ltd., Cambridge, UK) was used to obtain a diurnal cycle of stomatal conductance $\left(g_{\mathrm{s}}\right)$, with measurements taken each day at 2-h intervals between 0800 hours and 1600 hours, for a total of five measurements per day. Before each cycle of measurements, we recalibrated the instrument by using the Delta-T calibration plate. Stomatal conductance on mistletoes was measured on both leaf surfaces and expressed as the sum of the two measurements.
Both mistletoe hosts had hypostomatic leaves, and stomatal conductance measurements were performed only in the abaxial surface. Leaf predawn $\left(\psi_{\mathrm{pd}}\right)$ and midday $\left(\psi_{\mathrm{md}}\right)$ water potentials were measured in the field using a pressure chamber (PMS Instrument Co., St, Albany, OR) before sunrise (0500 hours for $\psi_{\mathrm{pd}}$ ) and at noon (1200 hours for $\psi_{\text {md }}$ ), respectively.

We determined stomatal density and guard cell dimensions in mistletoes leaves. Laminas subjected to histochemical treatment were mounted with dissociated epidermis from the leaves collected during the wet season and inserted in a glacial acetic acid and hydrogen peroxide solution (1:1) (modified from Franklin 1945). After completion of the dissociation, the semi-permanent laminas were stained with safranin and mounted with glycerin. The images were obtained with an optical microscope (model CX31; Olympus, Tokyo, Japan) mounted with a digital camera (model C-7070; Olympus) and analysed with Image Pro-Plus software (Media Cybernetics Inc., Rockville, MD). The following traits were measured: stomatal density (number per square millimetre), length of guard cells (in micrometres) and the equatorial stomatal diameter (stomata width in micrometres). We measure 250 stomata in each sample, totalling 20 fields per leaf analysed under a $10 \times$ lens.

The software $\mathrm{R}$ version 3.0.1 ( $\mathrm{R}$ Development Core Team 2008) was used for all statistical analyses. Normality of the data was checked with Shapiro-Wilk test, which is appropriate for small sample sizes (Quinn and Keough 2002). The effects of season and phenology on the physiological parameters were determined by multivariate analysis of variance (MANOVA) for mistletoes and hosts separately, followed by univariate ANOVAs to test for individual effects of each of the five response variables. Pairwise comparisons between each season were performed in order to test for differences in photosynthetic rates $\left(A_{\max }\right)$, stomatal conductance $\left(g_{s-\max }\right)$, WUE and leaf water potential $(\psi)$ between host species, and between mistletoes parasitizing the deciduous and those parasitizing the evergreen host.

We compared mistletoe stomatal traits (density, length and width) from the different leaf surfaces between $P$. ovata growing on deciduous hosts and those growing on evergreen hosts using ANOVAs followed by Tukey's HSD tests. Finally, to evaluate whether the differences in these traits were actually reflecting physiological differences, we performed Pearson's correlation between stomatal traits and stomatal conductance for $P$. ovata parasitizing the two different hosts. Differences in these bivariate relationships were tested using the Standardised Major Axis Tests and Routines (SMATR) software program (Warton et al. 2012). For all tests, differences were considered to be significant at $P<0.05$. 
Table 1 Multivariate analysis of variance for the effects of phenology and season on leaf parameters of the two host plant species (the evergreen Miconia albicans and deciduous Byrsonima verbascifolia) and their parasitizing mistletoes (Passovia ovata)

\begin{tabular}{llll}
\hline Source of variation & $d f$ & $F$ value & $P$ value \\
\hline Hosts & & & \\
$\quad$ Leaf phenology & 5.10 & 8.780 & $0.002^{*}$ \\
$\quad$ Season & 5.10 & 3.974 & $0.030^{*}$ \\
$\quad$ Leaf phenology $\times$ season & 5.10 & 5.758 & $0.009^{*}$ \\
Mistletoes & & & \\
$\quad$ Leaf phenology of the host & 5.10 & 0.554 & 0.732 \\
$\quad$ Season & 5.10 & 8.115 & $0.003^{*}$ \\
$\quad$ Leaf phenology of the host $\times$ season & 5.10 & 2.396 & 0.092 \\
\hline
\end{tabular}

* Significantly different at $P<0.05$

${ }^{\text {a }}$ Leaf phenology parameters were: maximum photosynthetic rate $\left(A_{\max }\right)$, maximum stomatal conductance $\left(g_{\text {s-max }}\right)$, transpiration $(E)$ and pre-dawn $\left(\psi_{\mathrm{pd}}\right)$ and midday $\left(\psi_{\mathrm{md}}\right)$ water potential $(\psi)$

\section{Results}

\section{Seasonal changes in leaf gas exchange and leaf water potential}

There were significant effects of season, type of leaf phenology and the interaction between season and leaf phenology for the gas exchange parameters of host species (Tables 1, 2). Maximum photosynthetic rates of both hosts decreased in a similar magnitude from wet to dry season (Table 2; Fig. 1a). The lower $A_{\max }$ of the evergreen host in the dry season compared to the wet season was associated with a concomitant decrease in $g_{\text {s-max }}$, while the lower $A_{\text {max }}$ of the deciduous host in the dry season was probably associated to some other factor, such as leaf senescence, because similar values of $g_{\text {s-max }}$ were measured in the dry and the wet season in the deciduous host (Fig. 1a, c). As a result, $g_{\text {s-max }}$ of the deciduous host was lower than that of the evergreen host during the wet season, but similar to that of the evergreen host in the dry season (ANOVA $F=3.89$; $P<0.05$ for the interaction host phenology $\times$ season; Table 2; Fig. 1c). The decrease in $A_{\max }$ combined with unchanged $g_{\text {s-max }}$ was reflected in lower WUE values for the deciduous host compared to the evergreen host in the dry season (Fig. 1e).

When all leaf parameters were considered together, there was no significant interaction effect between season and phenology of the host for mistletoes (Table 1), suggesting that, overall, the mistletoes showed similar behaviour between dry and wet seasons irrespectively of the host phenology. However, univariate analysis revealed that the parasitizing mistletoes displayed contrasting patterns of $A_{\text {max }}$ and $g_{\text {s-max }}$ that was host-dependent (Fig. 1). Mistletoes parasitizing the evergreen host decreased $A_{\max }$ and $g_{\text {s-max }}$ during the dry season (paired $t$ tests $P<0.05$ ), while mistletoes parasitizing the deciduous host maintained a similar $A_{\max }$ in both seasons but increased $g_{\text {s-max }}$
Table 2 Univariate analysis of variance for each of the response variables tested: maximum photosynthetic rates, maximum stomatal conductance, transpiration, predawn leaf water potential and midday leaf water potential, for mistletoes and hosts separately

\begin{tabular}{|c|c|c|c|c|c|c|c|}
\hline \multicolumn{4}{|l|}{ Mistletoe } & \multicolumn{4}{|l|}{ Host } \\
\hline Source of variation & $d f$ & $F$ value & $P$ value & Source of variation & $d f$ & $F$ value & $P$ value \\
\hline Phenology of the host & 1,14 & & & Phenology & 1,14 & & \\
\hline$A_{\max }$ & & 1.182 & 0.295 & $A_{\max }$ & & 4.732 & $0.047 *$ \\
\hline$g_{\text {s-max }}$ & & 0.006 & 0.937 & $g_{s-\max }$ & & 0.089 & 0.769 \\
\hline$E$ & & 0.014 & 0.908 & $E$ & & 0.565 & 0.464 \\
\hline$\psi_{\mathrm{pd}}$ & & 1.961 & 0.183 & $\psi_{\mathrm{pd}}$ & & 3.534 & 0.081 \\
\hline$\psi_{\mathrm{md}}$ & & 0.067 & 0.799 & $\psi_{\mathrm{md}}$ & & 20.315 & $<0.001^{*}$ \\
\hline Season & 1,14 & & & Season & 1,14 & & \\
\hline$A_{\max }$ & & 0.736 & 0.405 & $A_{\max }$ & & 6.527 & $0.023 *$ \\
\hline$g_{\text {s-max }}$ & & 0.679 & 0.424 & $g_{\text {s-max }}$ & & 14.664 & $0.002 *$ \\
\hline$E$ & & 0.197 & 0.664 & $E$ & & 1.872 & 0.193 \\
\hline$\psi_{\mathrm{pd}}$ & & 23.730 & $<0.001 *$ & $\psi_{\mathrm{pd}}$ & & 2.662 & 0.111 \\
\hline$\psi_{\mathrm{md}}$ & & 36.032 & $<0.001 *$ & $\psi_{\mathrm{md}}$ & & 1.287 & 0.276 \\
\hline Phenology of the host $\times$ season & 1,14 & & & Phenology $\times$ season & 1,14 & & \\
\hline$A_{\max }$ & & 3.439 & $0.041^{*}$ & $A_{\max }$ & & 0.066 & 0.800 \\
\hline$g_{s-\max }$ & & 4.603 & $0.040^{*}$ & $g_{s-\max }$ & & 3.886 & $0.049 *$ \\
\hline$E$ & & 10.543 & $0.006^{*}$ & $E$ & & 14.919 & $0.002 *$ \\
\hline$\psi_{\mathrm{pd}}$ & & 2.325 & 0.149 & $\psi_{\mathrm{pd}}$ & & 0.141 & 0.172 \\
\hline$\psi_{\mathrm{md}}$ & & 0.325 & 0.577 & $\psi_{\mathrm{md}}$ & & 5.035 & $0.041 *$ \\
\hline
\end{tabular}

* Significantly different at $P<0.05$ 
Fig. 1 Pair-wise comparisons between wet (grey boxes) and dry (white boxes) seasons for maximum photosynthetic rates $\left(A_{\max } ; \mathbf{a}, \mathbf{b}\right)$, maximum stomatal conductance $\left(g_{s-\max } ; \mathbf{c}, \mathbf{d}\right)$ and water use efficiency $(W U E ; \mathbf{e}, \mathbf{f})$ for the evergreen host Miconia albicans and the deciduous host Byrsonima verbascifolia (a, c, e) and the attached mistletoe Passovia ovata (b, d, f). Thick horizontal line in box Median, error bars 10 and 90 percentiles, respectively, small open circles outliers. Asterisk denotes significant differences between the dry and wet seasons at $P<0.05$
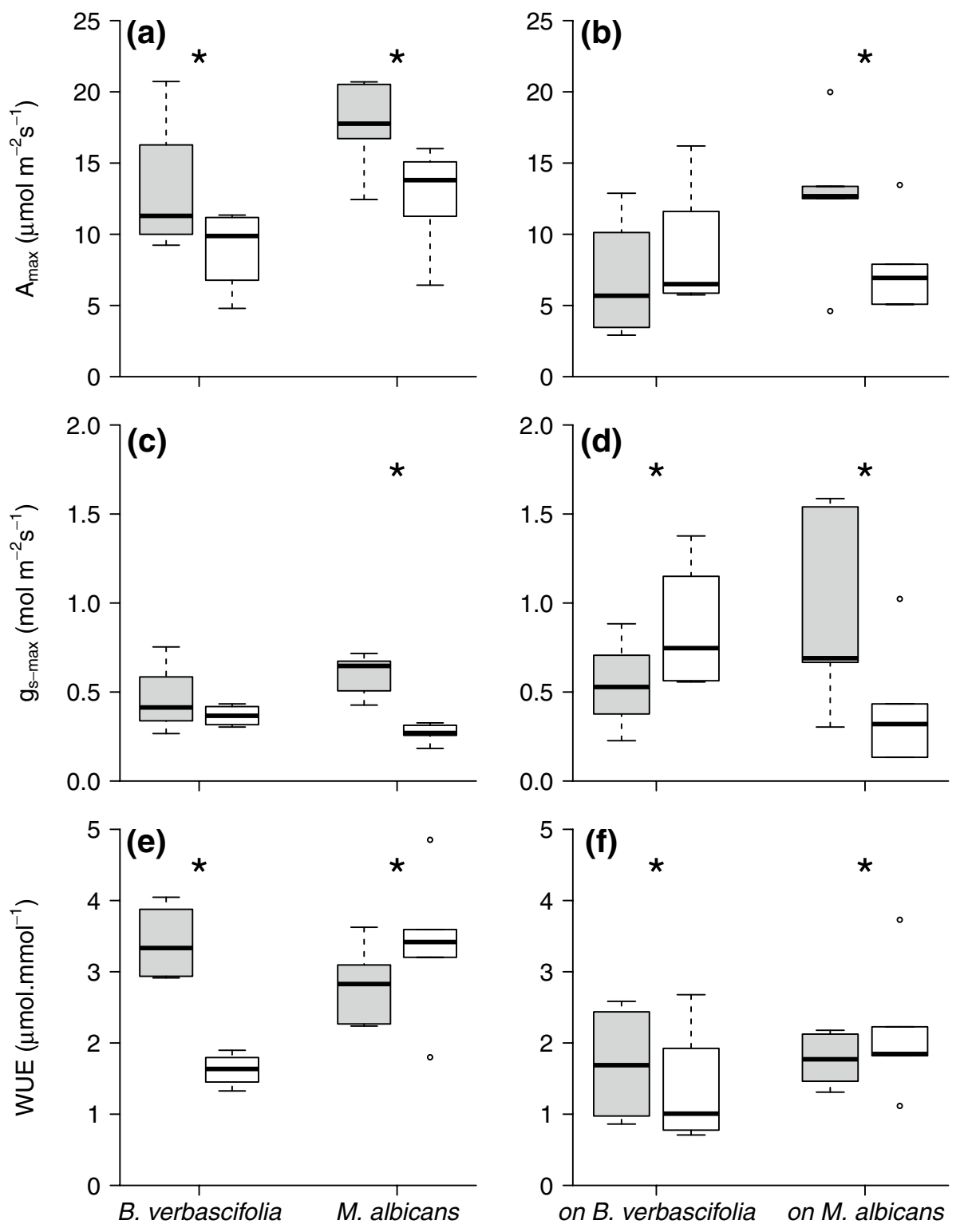

Host

Mistletoe in the dry season (Fig. 1b, d). Therefore, P. ovata on the deciduous host showed a higher $g_{\text {s-max }}$ than P. ovata on the evergreen host in the dry season, but there was not difference in $g_{\text {s-max }}$ between $P$. ovata on the different hosts during the wet season (ANOVA $F=4.60, P=0.04$ for the interactions host phenology $\times$ season; Table 2, Fig. 1d). $P$. ovata on both hosts showed similar values of WUE in the wet season (Fig. 1f). In contrast, WUE of the mistletoe on the evergreen host increased in the dry season (paired $t$ test, $P<0.01$ ), while WUE of $P$. ovata on the deciduous host decreased (paired $t$ test, $P<0.01$, Fig. 1f).

Despite the deciduous behaviour of $B$. verbascifolia, during the measurements taken at the peak of the dry season, plants still had a few mature to senescent leaves attached (i.e. the abscission layer was still not formed). In order to confirm that the mistletoe would be able to maintain the water flux in the complete absence of leaves in the host plant, we performed a second set of gas exchange measurements in the same $P$. ovata individuals after the deciduous host had lost all the leaves. There was no significant difference between the first and second set of measurements [paired $t$ tests: all $P>0.1$; Electronic Supplementary Material (ESM) 1].

The midday water potential ( $\psi_{\mathrm{md}}$ ) values of the deciduous host $B$. verbascifolia were less negative than those of the evergreen host $M$. albicans, reflecting a lower amplitude in water potential $(\Delta \psi)$ during the day (ANOVA $F=5.04$, $P=0.041$ for the interaction host phenology $\times$ season; 


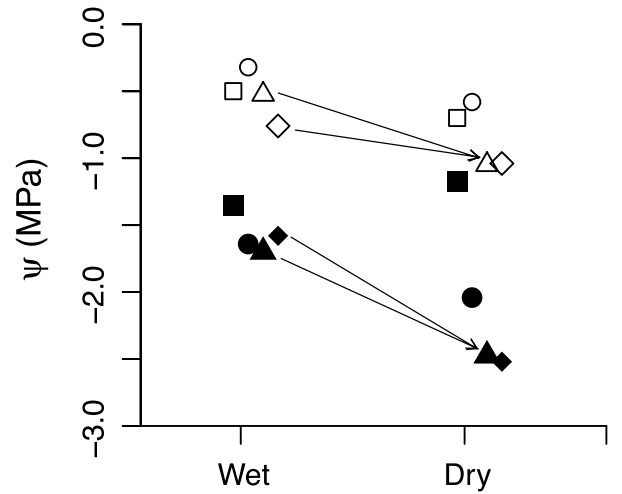

Fig. 2 Pre-dawn (open symbols) and midday (closed symbols) water potential $(\psi)$ for the evergreen host $M$. albicans (circles), the deciduous host $B$. verbascifolia (squares) and the mistletoe $P$. ovata parasitizing the evergreen host (diamonds) and the deciduous host (triangles) during the wet and the dry seasons. Arrows indicate significant differences between the wet and dry seasons for mistletoes $(P<0.05)$. Seasonal differences were not significant $(P>0.05)$ for hosts. Statistical tests, means and standard errors (SE) are shown in ESM 2

Table 2; Fig. 2). Despite generally maintaining similar leaf water potential values on both hosts, there was a significant seasonal effect on $\psi_{\mathrm{pd}}$ and $\psi_{\mathrm{md}}$ for $P$. ovata $(P<0.001$ for both cases; Table 2; Fig. 2). Moreover, P. ovata on the evergreen host showed a larger $\Delta \psi$ during the dry season than during the wet season (ESM 2).

\section{Stomatal behaviour and morphology}

The diurnal courses of $g_{\mathrm{s}}$ for host plants and associated mistletoes at the peak of the dry and wet seasons showed that mistletoes maintained higher $g_{\mathrm{s}}$ than their hosts for most of the day in the two seasons (ESM 3). When the diurnal course of $g_{\mathrm{s}}$ of the host was plotted against the corresponding diurnal course of $g_{\mathrm{s}}$ of the attached mistletoe, hysteresis in mistletoe $g_{\mathrm{s}}$ was observed in both the wet and dry seasons (Fig. 3a, b). We also found a clear effect of the dry period on $g_{\mathrm{s}}$. For both mistletoe-host pairs, the curve was strongly compressed during the dry season (i.e. smaller range in $g_{\mathrm{s}}$ values); however, the impact of the dry period was more conspicuous for mistletoes parasitizing the evergreen host, which showed not only a smaller amplitude in $g_{\mathrm{s}}$, but also lower minimum and maximum $g_{\mathrm{s}}$ than mistletoes parasitizing the deciduous host (Fig. 3; ESM 3).

Stomatal density on both leaf surfaces of $P$. ovata on the deciduous host was lower than that on both leaf surfaces of $P$. ovata on the evergreen host (Table 3; ESM 4). The stomata of mistletoes parasitizing the deciduous host were also wider, although there were no differences in stomatal length (Table 3; ESM 4). The stomatal ratio between the adaxial and abaxial leaf surfaces was $1.43 \pm 0.16$ and did
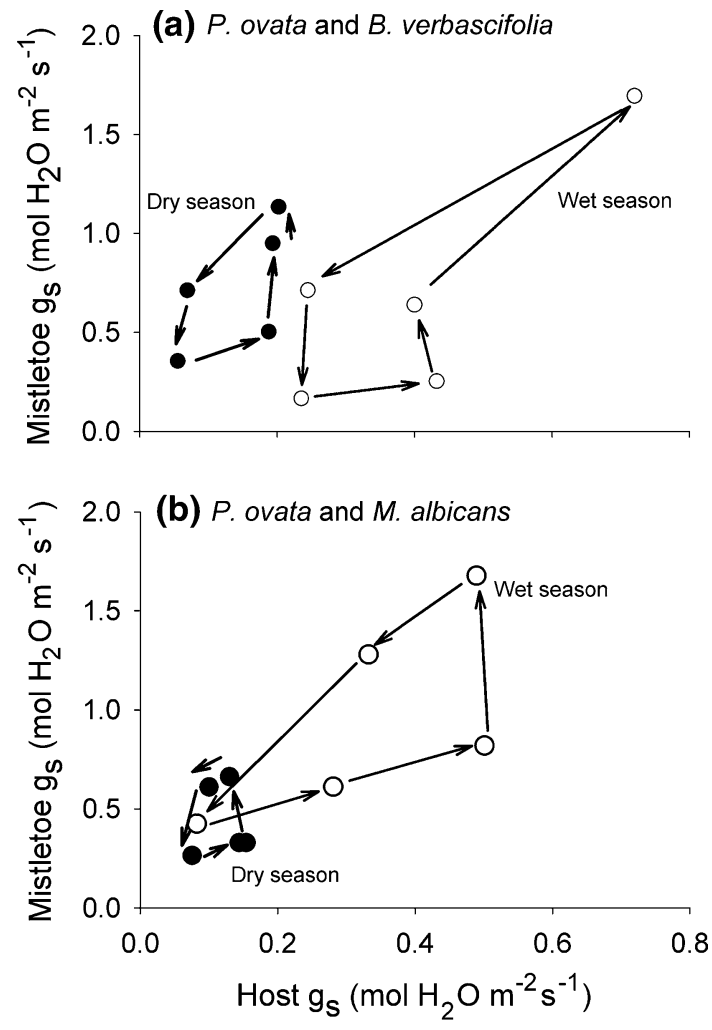

Fig. 3 Interdependence between the stomatal conductance $\left(g_{s}\right)$ of the mistletoe $P$. ovata and the deciduous host $B$. verbascifolia (a), and between $P$. ovata and the evergreen host $M$. albicans (b), for dry (filled symbols) and wet (open symbols) seasons. Values are means for diurnal courses as shown in ESM 3. The direction of the arrows represents variation during the course of the day

not differ between mistletoes parasitizing the evergreen and deciduous hosts. Stomatal density and $g_{s-\max }$ were highly correlated (Fig. 4), but individual slopes were significantly different depending on the host, with a much steeper relationship for the mistletoe associated with the evergreen host $(P=0.007$; Fig. 4$)$. No significant correlations were found between the other stomatal traits and $g_{\mathrm{s}}(P>0.05$ for all cases).

\section{Discussion}

In highly seasonal environments, plants must be able to physiologically and morphologically deal with water shortage situations. However, the adaptive responses of parasitic plants to such pressures may differ, especially if they are able to parasitize a wide range of hosts. In this context, our key expectation was fulfilled. Mistletoes showed tighter regulation of water loss when parasitizing an evergreen host than when parasitizing a deciduous one. Differences were also found in the stomatal anatomical traits, where $P$. ovata on the deciduous host showed lower stomatal 
Table 3 Stomatal traits of mistletoe $P$. ovata parasitizing the deciduous host $B$. verbascifolia and the evergreen host $M$. albicans

\begin{tabular}{llccc}
\hline Stomatal traits & Leaf surface & P. ovata on B. verbascifolia & P. ovata on M. albicans & ANOVA results \\
\hline Stomatal density $\left(\right.$ number $\mathrm{mm}^{-2}$ ) & Abaxial & $107.30 \pm 4.38 \mathrm{a}$ & $147.97 \pm 5.66 \mathrm{c}$ & $F=24.64, P<0.001$ \\
& Adaxial & $71.92 \pm 7.22 \mathrm{~b}$ & $102.61 \pm 5.99 \mathrm{a}$ & \\
Stomata width $(\mu \mathrm{m})$ & Abaxial & $38.52 \pm 0.85 \mathrm{a}$ & $34.55 \pm 0.65 \mathrm{~b}$ & $F=7.77, P=0.03$ \\
& Adaxial & $34.75 \pm 1.18 \mathrm{~b}$ & $32.72 \pm 0.34 \mathrm{~b}$ & \\
Stomata length $(\mu \mathrm{m})$ & Abaxial & $53.83 \pm 1.71 \mathrm{a}$ & $48.15 \pm 2.08 \mathrm{~b}$ & $F=2.37, P=0.114$ \\
& Adaxial & $49.79 \pm 2.03 \mathrm{~b}$ & $45.87 \pm 2.35 \mathrm{~b}$ & \\
\hline
\end{tabular}

Values shown are the results of the analysis of variance for each of the stomatal traits for the mistletoes on the two hosts, presented as the mean \pm standard error $(n=5$ measurements). Different lowercase letters indicate signficant differences between hosts and leaf surfaces at $P<0.05$

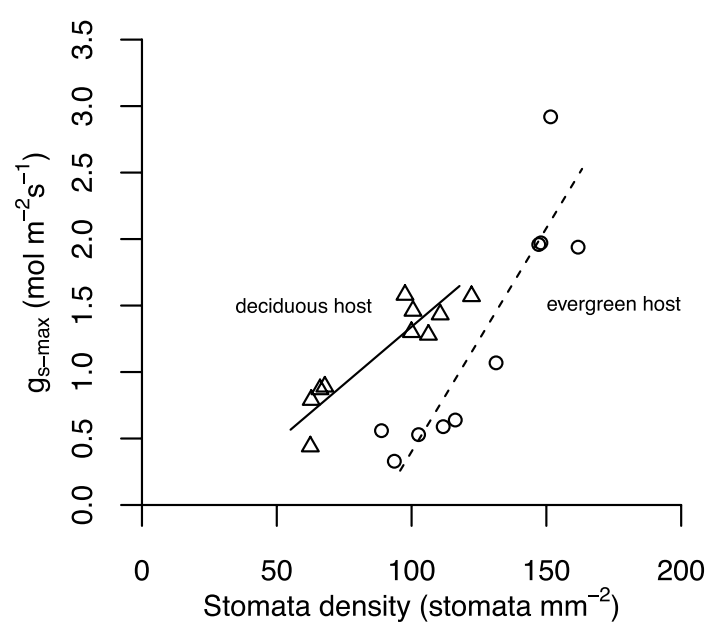

Fig. 4 Standardized major axis (SMA) relationship between stomatal density and maximum stomatal conductance $\left(g_{s-\max }\right)$ for abaxial and adaxial leaf surfaces of $P$. ovata parasitizing the evergreen host M. albicans (circles, dashed line) and the deciduous host B. verbascifolia (triangles, continuous line). Individual slopes were different ( $P=0.007)$. SMA description: $P$. ovata on $M$. albicans: slope 3.45 , $95 \%$ confidence interval (CI) 2.59-4.61), $r^{2}=0.87$; P. ovata on $B$. verbascifolia: slope $1.56,95 \%$ CI $1.06-2.28, r^{2}=0.77$

density and wider stomata. Taken together, these results suggest that mistletoes parasitizing evergreen hosts are more constrained to regulate water loss than plants of the same mistletoe species parasitizing deciduous hosts. Furthermore, our results provide evidence that $P$. ovata shows morphophysiological plasticity according to the host it is parasitizing.

\section{Seasonal changes in leaf gas exchange and leaf water potential}

The majority of Cerrado woody species considerably restrict the stomatal aperture during the dry season because of the high solar irradiation, high temperatures, low air relative humidity and restricted soil water availability (Bucci et al. 2004; Franco et al. 2005; Meinzer et al. 1999). We found that $P$. ovata growing on the evergreen $M$. albicans decreased their $A_{\max }$ and $g_{\text {s-max }}$, thereby increasing WUE, from the wet to the dry season (Fig. 1). In comparison, $P$. ovata growing on the deciduous $B$. verbascifolia increased their $g_{s-\max }$ but maintained $A_{\max }$ at the same level, thereby reducing WUE, from the wet to the dry season (Fig. 1b, $d, f)$. The differences might be explained by the contrasting patterns of leaf phenology of the two hosts. While the evergreen $M$. albicans maintains a green canopy during the dry season, the deciduous $B$. verbascifolia drops its leaves and remains leafless for a period of up to 3 weeks. In fact, we observed that $P$. ovata was capable of maintaining the water flux through the deciduous host even when the host had no leaves at all (ESM 1). When water is limited, mistletoes compete for water with the branches of the host tree (Glatzel and Geils 2009). Based on our results, mistletoes parasitizing deciduous trees may have an advantage over those parasitizing evergreens due to reduced competition with host leaves during the most critical period of the year for water acquisition.

The regulation of plant water balance was significantly different between the host and the attached mistletoe. Mistletoes attained a more negative minimum leaf $\psi$ during the dry season than during the wet season, showing an anisohydric behaviour, in contrast to the isohydric behaviour of the host, which maintained similar $\psi$ values throughout the year (Fig. 2). The small seasonal variation in leaf water status in Cerrado woody trees suggests that they have access to soil water throughout the year (Bucci et al. 2005; Meinzer et al. 1999; Rawitscher 1948; Scholz et al. 2002). However, access to soil water reserves would not be enough to maintain a relatively stable plant water balance in a seasonal environment subjected to a long dry season coupled with a strong atmospheric evaporative demand. Isohydric behaviour can only be maintained through strong stomatal control and a concomitant decrease in the leaf surface area in a dry season, together with other compensatory mechanisms (Bucci et al. 2005). Mistletoes, on the other hand, may experience a more relaxed selective pressure to optimize the use of water, achieving a more negative $\psi$ in the dry season (Fig. 2; ESM 2). However, we observed that 
during the dry season both hosts and mistletoes showed a small seasonal variation in $\psi$ amplitude $(\Delta \psi)$ and tighter stomatal control of transpirational losses, which suggests that mistletoes, particularly those on evergreen hosts, are strongly constrained by both the high atmospheric evaporative demand during the dry season and hydraulic limitations imposed on the host plant (Meinzer et al. 1999).

\section{Stomatal behaviour and morphology}

The observed diurnal cycles of stomatal conductance (ESM 3) and the relationship between host and mistletoe $g_{s}$ throughout the day (Fig. 3) partially corroborated a conservative water use strategy and showed coordinated stomatal control between mistletoes and their hosts. Although stomatal conductance was higher in the mistletoes than in the host plants during most of the day, both mistletoes and hosts maintained similar daily patterns of stomatal conductance which, during the wet season, consisted of a peak at noon, followed by a continuous decrease until the end of the day. However, mistletoes were not as constrained as the host plants: during extreme drought stress conditions (dry season), host stomata remained virtually closed during most of the day, while those of the parasitizing mistletoes were maintained partially open; this was especially evident for P. ovata on B. verbascifolia.

Ullmann et al. (1985) measured the diurnal stomatal conductance in 19 mistletoe-host pairs in arid and semiarid environments in Australia and concluded that mistletoes likely possess a mechanism to restrict transpiration. In that study, the studied mistletoe species showed a clear coordination with host physiological behaviour in terms of similar patterns of diurnal cycle, which is similar to our results for Cerrado mistletoes. The authors suggested that this correspondence could occur because of similar responses to external factors, such as the water VPD (Ullmann et al. 1985). In a global analysis, Scalon and Wright (2015) showed that mistletoes become more conservative in their water use with increasing aridity, suggesting that they respond to environmental constraints in a manner similar to that of their hosts. Alternatively, mistletoes could be responding to an internal mechanism driven by the host, such as hormonal control, as suggested by Ullmann et al. (1985). Even though our study was restricted to a small spatial scale, our results support the latter notion, since the same species of mistletoe in the same site (e.g. subjected to similar VPD) showed different stomatal behaviour depending on the host to which it was attached (Fig. 3).

In our study, $P$. ovata also exhibited plasticity on stomatal anatomical traits that resulted in unique relationships between stomatal conductance and stomata density depending on the host it was parasitizing. On the deciduous host, $P$. ovata had fewer, but larger stomata, which suggests an increased access to water compared to the mistletoe on the evergreen host. Increasing stomatal density and decreasing stomatal size are related to water deficit (Cutler et al. 1977; Hetherington and Woodward 2003; Spence et al. 1986; Xu and Zhou 2008). Higher stomatal density is associated to lower water availability due to a better stomatal control in regulating water loss by transpiration (Lleras 1977; Sachs 2005). Therefore, the differences in stomatal density which we found for $P$. ovata on the different hosts could be attributed to the distinct water use strategy of the host species. In fact, deciduous tree species from the Brazilian Cerrado not only drop their leaves in the dry season, which greatly reduces their water demand, but they generally have deeper roots and more reliable water sources than evergreen species (Jackson et al. 1999).

Undoubtedly, other aspects related to life history might need to be considered. For example, architectural variation could possibly influence physiological responses. In terms of individual differences, the place of attachment of mistletoe to the deciduous host tended to be higher (mean \pm standard error: $94.87 \pm 9.18 \mathrm{~cm} ; n=5$ ) than that of its counterpart to the evergreen host $(49.10 \pm 9.86 \mathrm{~cm}$; $n=5$ ). This higher position, in combination with the deciduous characteristic of the host, has the potential to affect light incidence, which in turn can affect the stomata density of the newly forming leaves (Casson and Gray 2008). However, irrespective of the deciduous or evergreen nature of the host, all sampled individual $P$. ovata plants had similar total number of leaves and leaf area (ESM 5).

In a study comparing gallery forest (Cerrado humid forest formation) and Cerrado sensu stricto species, Rossatto et al. (2009) reported that stomata length values ranged from 15 and $45 \mu \mathrm{m}$, which is a much lower range than that observed for the mistletoe in our study. Larger stomata are usually found in mesophytic environments because of the slower response of plants and abundant water consumption (Galmés et al. 2007), while smaller stomata tend to be found in xeric environments, where a tighter control of water loss is essential (Aasamaa et al. 2001). Our result is not surprising since mistletoes evolved under different selective pressures than the species studied by Rossatto et al. (2009) and because the water unit-cost is probably much lower for parasitic plants (Scalon and Wright 2015). We suggest that higher stomatal density and larger stomata sizes might be a trend among other mistletoe species, as previously reported for another species of the same genus, Passovia pyrifolia (El-Sharkawy et al. 1986) and for different species of mistletoes from the Viscaceae family, such as Phoradendron villosum (Hollinger 1983) and Viscum album (Escher et al. 2008).

Whether selective pressures imposed by the colonization of hosts with contrasting leaf phenologies are sufficiently strong to result in the evolution of different host races of $P$. 
ovata is currently not known. This phenomenon has been described for many different species, such as Phoradendron tomentosum (Clay et al. 1985), Phoradendron californicum (Glazner et al. 1988), Arceuthobium americanum (Jerome and Ford 2002), and Viscum album (Zuber and Widmer 2009), suggesting that host identity is a factor causing genetic differentiation between mistletoe races. However, most of these studies considered geographic areas that were larger than our study site, where both hosts are growing sympatrically within the same site, which would favour host race formation.

To the best of our knowledge, this is the first study to show morphophysiological differences in the same mistletoe species attached to deciduous and evergreen hosts. We have shown that mistletoe and host diurnal courses of stomatal conductance were coupled across the different seasons and that deciduous plants are capable of maintaining the flow of water through the xylem water flux even after leaves had dropped, suggesting that the maintenance of host vascular system integrity during the leafless period. More broadly, our results suggest that phenotypical plasticity might favour generalist mistletoes, allowing them to cope with the physiological particularities of a range of different hosts.

Acknowledgments MCS is supported by a postdoctoral fellowship from $\mathrm{CNPq}$ (Conselho Nacional de Desenvolvimento Científico e Tecnológico). ACF is recipient of a $\mathrm{CNPq}$ Research Productivity fellowship (303637/2011-0) and Universal-CNPq research Grant (484545/2012-4). We thank RECOR/IBGE for the logistic support and Fred Takahashi for the help in the fieldwork. This is publication number 18 in the Parasitic Plants Research Group Technical Series.

Author contribution statement MCS, ACF and DRR conceived and designed the study. MCS, DRRand FMCBD conducted fieldwork and performed statistical analyses. MCS performed theanatomical analysis and wrote the manuscript with help from other authors.

\section{References}

Aasamaa K, Sõber A, Rahi M (2001) Leaf anatomical characteristics associated with shoot hydraulic conductance, stomatal conductance and stomatal sensitivity to changes of leaf water status in temperate deciduous trees. Funct Plant Biol 28:765-774

Arruda R, Fadini RF, Carvalho LN et al (2012) Ecology of Neotropical mistletoes: an important canopy-dwelling component of Brazilian ecosystems. Acta Bot Bras 26:264-274

Atsatt P (1970) Hemiparasitic flowering plants: phenotypic canalization by hosts. Nature 225:1161

Bowie M, Ward D (2004) Water and nutrient status of the mistletoe Plicosepalus acaciae parasitic on isolated Negev Desert populations of Acacia raddiana differing in level of mortality. J Arid Environ 56:487-508

Bucci SJ, Goldstein G, Meinzer FC, Scholz FG, Franco AC, Bustamante M (2004) Functional convergence in hydraulic architecture and water relations of tropical savanna trees: from leaf to whole plant. Tree Physiol 24:891-899
Bucci SJ, Goldstein G, Meinzer FC, Franco AC, Campanello P, Scholz FG (2005) Mechanisms contributing to seasonal homeostasis of minimum leaf water potential and predawn disequilibrium between soil and plant water potential in Neotropical savanna trees. Trees Struct Funct 19:296-304

Buen LL-D, Ornelas JF (1999) Frugivorous birds, host selection and the mistletoe Psittacanthus schiedeanus, in central Veracruz, Mexico. J Trop Ecol 15:329-340

Calder M, Bernhardt P (1983) The biology of mistletoes. Academic Press, Sydney

Casson S, Gray JE (2008) Influence of environmental factors on stomatal development. New Phytol 178:9-23

Clay K, Dement D, Rejmanek M (1985) Experimental evidence for host races in mistletoe (Phoradendron tomentosum). Am J Bot 72:1225-1231

Cutler J, Rains D, Loomis R (1977) The importance of cell size in the water relations of plants. Physiol Plant 40:255-260

Davidson NJ, Pate JS (1992) Water relations of the mistletoe Amyema fitzgeraldii and its host Acacia acuminata. J Exp Bot 43:1549-1555

Davidson NJ, True KC, Pate JS (1989) Water relations of the parasite: host relationship between the mistletoe Amyema linophyllum (Fenzl) Tieghem and Casuarina obesa Miq. Oecologia 80:321-330

El-Sharkawy MA, Cock JH, Hernandez ADP (1986) Differential response of stomata to air humidity in the parasitic mistletoe (Phthirusa pyrifolia) and its host, mandarin orange (Citrus resitulata). Photosynth Res 9:333-343

Escher P, Eiblmeier M, Hetzger I, Rennenberg H (2004) Spatial and seasonal variation in amino compounds in the xylem sap of a mistletoe (Viscum album) and its hosts (Populus spp. and Abies alba). Tree Physiol 24:639-650

Escher P, Peuke AD, Bannister P et al (2008) Transpiration, $\mathrm{CO}_{2}$ assimilation, WUE, and stomatal aperture in leaves of Viscum album (L.): effect of abscisic acid (ABA) in the xylem sap of its host (Populus euamericana). Plant Physiol Biochem 46:64-70

Franco AC, Bustamante M, Caldas LS et al (2005) Leaf functional traits of Neotropical savanna trees in relation to seasonal water deficit. Trees Struct Funct 19:326-335

Franklin G (1945) Preparation of thin sections of synthetic resins and wood-resin composites, and a new macerating method for wood. Nature 155:51

Galmés J, Flexas J, Savé R, Medrano H (2007) Water relations and stomatal characteristics of Mediterranean plants with different growth forms and leaf habits: responses to water stress and recovery. Plant Soil 290:139-155

Garkoti S, Akoijam S, Singh S (2002) Ecology of water relations between mistletoe (Taxillus vestitus) and its host oak (Quercus floribunda). Trop Ecol 43:243-249

Glatzel G, Geils BW (2009) Mistletoe ecophysiology: host-parasite interactions. Botany 87:10-15

Glazner JT, Devlin B, Ellstrand NC (1988) Biochemical and morphological evidence for host race evolution in desert mistletoe, Phoradendron californicum (Viscaceae). Plant Syst Evol 161:13-21

Herrera CM (1988) Plant size, spacing patterns, and host-plant selection in Osyris quadripartita, a hemiparasitic dioecious shrub. J Ecol 76:995-1006

Hetherington AM, Woodward FI (2003) The role of stomata in sensing and driving environmental change. Nature 424:901-908

Hollinger DY (1983) Photosynthesis and water relations of the mistletoe, Phoradendron villosum, and its host, the California valley oak, Quercus lobata. Oecologia 60:396-400

Jackson PC, Meinzer FC, Bustamante M et al (1999) Partitioning of soil water among tree species in a Brazilian Cerrado ecosystem. Tree Physiol 19:717-724 
Jerome CA, Ford BA (2002) The discovery of three genetic races of the dwarf mistletoe Arceuthobium americanum (Viscaceae) provides insight into the evolution of parasitic angiosperms. Mol Ecol 11:387-405

Ladley JJ, Kelly D (1996) Dispersal, germination and survival of New Zealand mistletoes (Loranthaceae): dependence on birds. N Z J Ecol 20:69-79

Lleras E (1977) Differences in stomatal number per unit area within the same species under different micro environmental conditions: a working hypothesis. Acta Amazon 7:473-476

Lüttge U, Haridasan M, Fernandes GW et al (1998) Photosynthesis of mistletoes in relation to their hosts at various sites in tropical Brazil. Trees Struct Funct 12:167-174

Maitelli G, Miranda A (1991) Evapotranspiração e fluxos de energia no Cerrado-Estação Chuvosa. An Acad Bras Cienc 63:265-272

May DS (1972) Morphological and physiological differentiation of Phoradendron populations in Texas. Am J Bot 59:12-22

Medel RG, Vergara E, Silva A, Serey IA (1995) Variation of the architectural phenotype of Tristerix aphyllus in central Chile. Rev Chilena Hist Nat 68:451-458

Meinzer F, Goldstein G, Franco AC et al (1999) Atmospheric and hydraulic limitations on transpiration in Brazilian cerrado woody species. Funct Ecol 13:273-282

Miranda A, Miranda HC, Lloyd J et al (1997) Fluxes of carbon, water and energy over Brazilian cerrado: an analysis using eddy covariance and stable isotopes. Plant Cell Environ 20:315-328

Nickrent DL, Malécot V, Vidal-Russell R, Der JP (2010) A revised classification of Santalales. Taxon 59:538-558

Okubamichael DY, Griffiths ME, Ward D (2011) Host specificity, nutrient and water dynamics of the mistletoe Viscum rotundifolium and its potential host species in the Kalahari of South Africa. J Arid Environ 75:898-902

Press MC, Graves JD (1995) Parasitic plants. Chapman \& Hall Ltd, London

Press MC, Phoenix GK (2005) Impacts of parasitic plants on natural communities. New Phytol 166:737-751

Quinn GP, Keough MJ (2002) Experimental design and data analysis for biologists. Cambridge University Press, Cambridge

R Development Core Team (2008) R: a language and environment for statistical computing. R Foundation for Statistical Computing, Vienna, Austria

Rawitscher F (1948) The water economy of the vegetation of the Campos Cerrados' in Southern Brazil. J Ecol 36:237-268
Rawsthorne J, Watson DM, Roshier DA (2011) Implications of movement patterns of a dietary generalist for mistletoe seed dispersal. Austral Ecol 36:650-655

Rossatto DR, Hoffmann WA, Franco AC (2009) Stomatal traits of cerrado and gallery forest congeneric pairs growing in a transitional region in Central Brazil. Acta Bot Bras 23:499-508

Sachs T (2005) Pattern formation in plant tissues. Cambridge University Press, Cambridge

Scalon MC, Wright IJ (2015) A global analysis of water and nitrogen relationship between mistletoes and their hosts: broad-scale tests of old and enduring hypotheses. Funct Ecol 29:1114-1124. doi: 10.1111/1365-2435.12418

Scalon M, Haridasan M, Franco A (2013) A comparative study of aluminium and nutrient concentrations in mistletoes on aluminium-accumulating and non-accumulating hosts. Plant Biol $15: 851-857$

Scholz FG, Bucci SJ, Goldstein G, Meinzer FC, Franco AC (2002) Hydraulic redistribution of soil water by neotropical savanna trees. Tree Physiol 22:603-612

Shen H, Ye W, Hong L et al (2006) Progress in parasitic plant biology: host selection and nutrient transfer. Plant Biol 8:175-185

Spence R, Wu H, Sharpe P, Clark K (1986) Water stress effects on guard cell anatomy and the mechanical advantage of the epidermal cells. Plant,Cell Environ 9:197-202

Stewart GR, Press MC (1990) The physiology and biochemistry of parasitic angiosperms. Annu Rev Plant Biol 41:127-151

Ullmann I, Lange O, Ziegler H, Ehleringer J, Schulze ED, Cowan I (1985) Diurnal courses of leaf conductance and transpiration of mistletoes and their hosts in Central Australia. Oecologia 67:577-587

Vidal-Russell R, Nickrent DL (2007) The biogeographic history of Loranthaceae. Darwiniana 45:52-54

Warton DI, Duursma RA, Falster DS, Taskinen S (2012) Smatr 3-an $\mathrm{R}$ package for estimation and inference about allometric lines. Methods Ecol Evol 3:257-259

Xu Z, Zhou G (2008) Responses of leaf stomatal density to water status and its relationship with photosynthesis in a grass. J Exp Bot 59:3317-3325

Zuber D, Widmer A (2009) Phylogeography and host race differentiation in the European mistletoe (Viscum album L.). Mol Ecol 18:1946-1962 